\title{
Evidence for Freshwater Residualism in Coho Salmon, Oncorhynchus kisutch, From a Watershed on the North Coast of British Columbia
}

\author{
Eric A. Parkinson ${ }^{1}$, Chris J. Perrin ${ }^{1}$, Daniel Ramos-Espinoza ${ }^{1}$, and Eric B. Taylor ${ }^{2,3}$ \\ ${ }^{1}$ Limnotek Research and Development Inc., Vancouver, British Columbia V6R 2X3 Canada \\ ${ }^{2}$ Department of Zoology, Biodiversity Research Centre and Beaty Biodiversity Museum, University of British Columbia, Van- \\ couver, British Columbia V6T 1Z4 Canada \\ ${ }^{3}$ Corresponding author: etaylor@zoology.ubc.ca
}

Parkinson, Eric A., Chris J. Perrin, Daniel Ramos-Espinoza, and Eric B. Taylor. 2016. Evidence for freshwater residualism in Coho Salmon, Oncorhynchus kisutch, from a watershed on the north coast of British Columbia. Canadian Field-Naturalist 130(4): 336-343.

The Coho Salmon, Oncorhynchus kisutch, is one of seven species of Pacific salmon and trout native to northeastern Pacific Ocean watersheds. The species is typically anadromous; adults reproduce in fresh water where juveniles reside for 1-2 years before seaward migration after which the majority of growth occurs in the ocean before maturation at 2-4 years old when adults return to fresh water to spawn. Here, we report maturation of Coho Salmon in two freshwater lakes on the north coast of British Columbia apparently without their being to sea. A total of 15 mature fish (11 males and four females) were collected in two lakes across two years. The mature fish were all at least $29 \mathrm{~cm}$ in total length and ranged in age from three to five years old. The occurrence of Coho Salmon that have matured in fresh water without first going to sea is exceedingly rare in their natural range, especially for females. Such mature Coho Salmon may represent residual and distinct breeding populations from those in adjacent streams. Alternatively, they may result from the ephemeral restriction in the opportunity to migrate seaward owing to low water levels in the spring when Coho Salmon typically migrate to sea after 1-2 years in fresh water. Regardless of their origin, the ability to mature in fresh water without seaward migration may represent important adaptive life history plasticity in response to variable environments.

Key Words: Life-history; Coho Salmon; morphology; genetic identification; sexual maturation; plasticity

\section{Introduction}

Pacific salmon and trout (Salmonidae: Oncorhynchus) comprise a complex of up to 12 species found from central Taiwan in the western Pacific, north and east through Japan, Russia, Alaska and south to northwestern Mexico (Groot and Margolis 1991; Behnke 1992). Across this range, Oncorhynchus species are renowned for their cultural, recreational, commercial, and scientific significance (Hendry and Stearns 2004; Lackey et al. 2006). The broad significance of Pacific salmon and trout has made them one of the best studied fishes with special attention on their life history (Groot and Margolis 1991; Quinn 2011).

Many species of salmon and trout are diadromous fishes, i.e., the life history of the group, to varying degrees, encompasses periods of time spent both in freshwater and marine environments (McDowell 1987). Specifically, Pacific salmon and trout are either permanent residents of fresh water (e.g., many species and sub-species of interior trout and kokanee) or anadromous, i.e., fish are born in fresh water, spend variable amounts of time there, migrate to sea to grow and mature, and return to fresh water to spawn (Pacific salmon and anadromous trout). In Pacific salmon and trout, a general evolutionary trend has been towards a lesser amount of time spent in fresh water. For instance, Pink Salmon, O. gorbuscha, that migrate to sea soon after emergence from their gravel nests and mature at two years old, occupy a more derived position in the evolutionary tree of Oncorhynchus than various species of Pacific basin trout that may be permanent residents of fresh water (Smith and Stearley 1989; Crête-Lafrenière et al. 2012). Notwithstanding this broad evolutionary pattern, many species show considerable variability in their expression of anadromy. Perhaps the best natural examples of such variability involve Sockeye Salmon and Kokanee, the anadromous and freshwater-resident forms of O. nerka (Ricker 1940) or Steelhead Trout and Rainbow Trout, the anadromous and non-anadromous forms of O. mykiss (Behnke 2002; Quinn 2011). In addition, Pink Salmon, Coho Salmon (O. kisutch), and Chinook Salmon (O. tshawytscha) have all established non-anadromous, but migratory, populations after introduction from their native range in the Pacific basin to the Great Lakes basin and, in the case of some Chinook Salmon, when introduced to New Zealand (McDowell 1990). In the case of Chinook Salmon, occasional reports of precocial maturation of male salmon, i.e., before migration to the sea, have been reported both in experimental and natural Pacific basin populations (Gebhards 1960; Taylor 1989). There have also been a few scattered reports of "residual" Coho Salmon (i.e., fish derived from anadromous parents that do not migrate to sea) in North America (e.g., Foerster and Ricker 
1953; Rousenfell 1958) and Asia (Berg 1948; Schmidt 1950). These residuals matured at varying rates and included both males and females, but no self-sustaining freshwater-resident populations in the native range of Coho Salmon are known. The phenomenon, however, appears to be very rare given that in British Columbia alone Coho Salmon are thought to comprise over 1300 populations spawning in about 300 streams (McPhail 2007; Quinn 2011).

In this paper, we report the occurrence of an apparently robust population of freshwater-resident Coho Salmon including both males and females and describe aspects of their life history inferred from analysis of growth patterns in scales and diets. The occurrence of freshwater-resident life history types of Coho Salmon adds further complexity to the design of conservation strategies to best represent biodiversity within this important species (e.g., Allendorf et al. 1997; Irvine and Fraser 2008; Taylor et al. 2011).

\section{Study Area}

Fishes were collected from a total of six lakes in west central British Columbia (Table 1) as part of a comprehensive biological and limnological sampling program to assess possible environmental impacts of the modernizing of a nearby aluminum smelter and associated increased sulphur dioxide emissions (ESSA Technologies Ltd. 2015). All the lakes were small, ranging from 2.3 to 10.3 ha in surface area (Table 1). Lak034 is just north of Terrace, British Columbia, while all other lakes are south of Terrace (Figure 1). All lakes have intermittent outlets that drain ultimately to the Skeena River drainage. End Lake and West Lake have no inlets and most inflow to the lakes likely comes from groundwater sources. End Lake was connected to Little End Lake by a common outlet channel that was $1 \mathrm{~m}$ deep and $2 \mathrm{~m}$ wide and edged with floating bog over its entire length. Water exchange between the two lakes is probably minimal, but fish can move between the lakes.

\section{Methods}

Fish sampling occurred during 7-11 October 2013 and 5-8 October 2015 when surface water temperature was in the range of $9.7-11.5^{\circ} \mathrm{C}$ and $8.3-11.2^{\circ} \mathrm{C}$, respectively. This was close to the optimal temperature for gill netting as estimated by Ward et al. (2012). Four nets were used in each lake; two were sinking Resource Inventory Committee (RIC) standard gill nets (RIC 1997), $91.2 \mathrm{~m}$ long and $2.4 \mathrm{~m}$ deep with six panels of different mesh sizes $(25,89,51,76,38$, and $64 \mathrm{~mm}$ stretched mesh). The other two were sinking fine mesh gill nets, $12.4 \mathrm{~m}$ long and $1.8 \mathrm{~m}$ deep with four equal length panels of different mesh sizes $(12.5,19,16,25$ $\mathrm{mm}$ stretched mesh). The fine mesh was uncoloured monofilament, $<0.13 \mathrm{~mm}$ for the three smallest meshes and $0.18 \mathrm{~mm}$ for the largest mesh size. The fine mesh nets were used to target small fishes and the RIC nets were used to target larger fishes. All nets were installed in late afternoon and recovered the following morning in littoral areas 1.5-6 m deep. The characteristics of each net set were recorded on a field form at the time of sampling (lake, unique set code, date, start and end time, geo-coordinates). Each fish captured was identified with lake number, date, unique set code, mesh size where the capture occurred, unique fish code, species code, and scale number. Each fish was also

TABLE 1. Lake names and characteristics sampled in 2013 and 2015. Also shown are the fork lengths, ages, and maturity status of Coho Salmon (Oncorhynchus kisutch) captured in five of the lakes. Maturity represents the presence ("Yes") or absence ("No") of mature fish within that age class. The "+" accompanying the age in years indicates that the fish is of an age somewhat older than the year listed. For instance, a $0+$ fish is in its first year of life and a $1+$ fish is estimated to be in its second year of life.

\begin{tabular}{|c|c|c|c|c|c|c|c|}
\hline Lake & $\begin{array}{c}\text { Area } \\
\text { (ha) }\end{array}$ & $\begin{array}{l}\text { Latitude, } \\
{ }^{\circ} \mathrm{N}\end{array}$ & $\begin{array}{l}\text { Longitude, } \\
{ }^{\circ} \mathrm{W}\end{array}$ & $\begin{array}{c}\text { Age } \\
\text { (years) }\end{array}$ & $n$ & $\begin{array}{l}\text { Fork length } \\
(\mathrm{cm}, \mathrm{SD})\end{array}$ & Maturity \\
\hline \multirow[t]{5}{*}{ West } & 6.77 & 54.3170 & 128.6503 & $1+$ & 2 & $20.3(1.4)$ & No \\
\hline & & & & $2+$ & 15 & $22.5(2.2)$ & No \\
\hline & & & & $3+$ & 10 & $25.8(3.0)$ & No \\
\hline & & & & $4+$ & 10 & $32.6(2.1)$ & Yes \\
\hline & & & & $5+$ & 5 & $31.4(2.3)$ & Yes \\
\hline \multirow[t]{4}{*}{ Little End } & 2.30 & 54.3365 & 128.6287 & $0+$ & 2 & $12.0(0.1)$ & No \\
\hline & & & & $1+$ & 11 & $19.3(1.6)$ & No \\
\hline & & & & $2+$ & 8 & $23.2(3.0)$ & No \\
\hline & & & & $3+$ & 1 & 31.0 (NA) & No \\
\hline \multirow[t]{4}{*}{ End } & 10.25 & 54.3332 & 128.6285 & $0+$ & 1 & 12.1 (NA) & No \\
\hline & & & & $1+$ & 8 & $17.6(3.3)$ & No \\
\hline & & & & $2+$ & 2 & $20.0(0.6)$ & No \\
\hline & & & & $3+$ & 1 & 26.5 (NA) & No \\
\hline \multirow[t]{2}{*}{ Lak007 } & 2.62 & 54.3093 & 128.5578 & $0+$ & 1 & 8.2 (NA) & No \\
\hline & & & & $1+$ & 5 & $11.7(0.9)$ & No \\
\hline \multirow[t]{2}{*}{ Lak016 } & 2.58 & 54.3115 & 128.6411 & $3+$ & 2 & $34.8(1.0)$ & Yes \\
\hline & & & & $4+$ & 1 & 35.5 (NA) & Yes \\
\hline Lak034 & 8.62 & 54.5931 & 128.6071 & NA & NA & NA & No \\
\hline
\end{tabular}




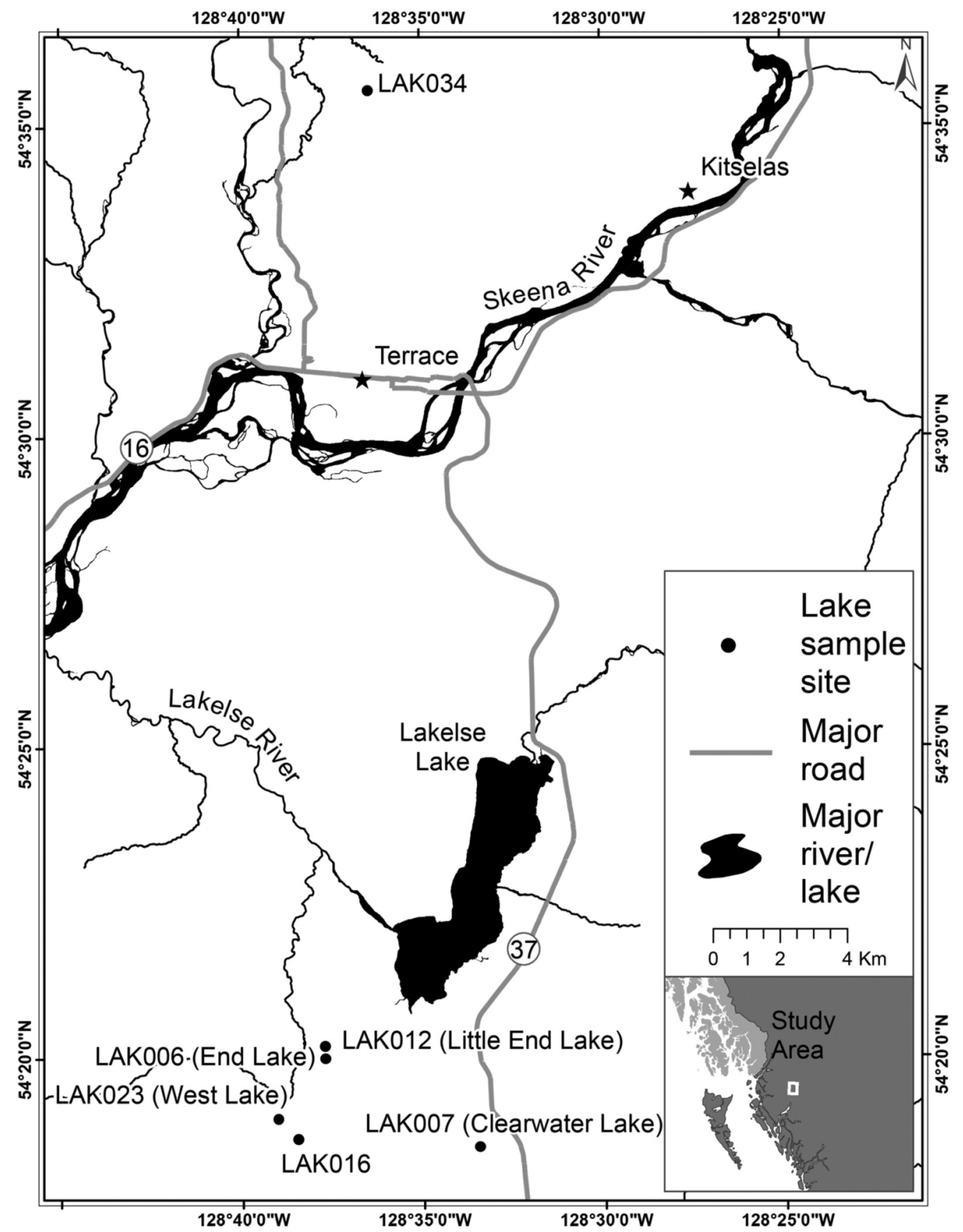

FIGURE 1. Locations of lakes sampled for fishes. The inset shows the study area within British Columbia, Canada.

measured to the nearest $0.1 \mathrm{~cm}$ (fork length), and weighed to the nearest $\mathrm{g}$ on an Ohaus Scout Pro SP4001 (Dundas, Ontario, Canada) top loading balance. Otoliths were removed from the head of each fish and scales were removed from a location between the posterior end of the dorsal fin and the lateral line. Both were stored in labeled envelopes for later aging using the methodology of Ward and Slaney (1988). For the 
Coho Salmon collected, maturity status was assessed after dissection and visual inspection of the abdominal cavity.

Each fish was identified to species in the field using the dichotomous field keys (Trautman 1973; Phillips 1977; McPhail 2007). Fish collected in 2013 and putatively identified in the field as Oncorhynchus spp. using the dichotomous keys above $(n=42)$ were also subject to DNA analysis to confirm identification. Here, four or five scales were taken and DNA was extracted using the Qiagen Blood and Tissue DNeasy extraction kits (Hilden, Germany) and kept at $4^{\circ} \mathrm{C}$ until analysis. The DNA was used in polymerase chain reaction (PCR) assays of variation at two loci that are diagnostic for differences among Coho and Chinook Salmon and Rainbow Trout (Greig et al. 2002; Ward et al. 2005). The first test is for a difference in the Growth Hormone2 (GH-2) intron and each species DNA fragment is a different size. Coho Salmon have GH-2 alleles that are less than 120 base pairs (bp) and typically $112-114 \mathrm{bp}$ in size, while Chinook Salmon and Rainbow Trout $(O$. mykiss) are characterized by 120 and 124 base pair alleles, respectively (Greig et al. 2002). Differences among species in GH-2 were resolved using electrophoresis (DNA fragment size fractionation) and laser detection after PCR with fluorescently-labelled primers using the methodology outlined by Greig et al. (2002). These differences are reported as fragments of different size (in base pairs) after electrophoresis on a BeckmanCoulter CEQ 8000 automated genotyper (Brea, California, USA). The species-specific differences have been verified by assaying Oncorhynchus from across the Pacific basin, including British Columbia (Greig et al. 2002).

The second test was conducted on only a subset of fish $(n=9)$ and assayed sequence differences in the mitochondrial DNA cytochrome oxidase I (CO1) gene that is the standard animal "barcoding" gene (Ward et al. 2005). A portion of the $\mathrm{CO} 1$ gene ( $\sim 650$ base pairs in length) was amplified from genomic DNA extracts using PCR and the materials and methodology described by Blanchfield et al. (2014). The amplified fragment was sequenced at the Nucleic Acid and Protein Service at the University of British Columbia. To identify the sequences taxonomically, the 'Identification' module of Barcode of Life Database Systems (BOLDSYSTEMS, http://www.boldsystems.org/, Ratnasingham and Hebert 2007) was used to calculate Kimura 2 parameter (K2P) genetic distances and clustered these by Neighbor-joining (NJ) tree analysis and provide a visual representation sequence identity against BOLD databases (Hubert et al. 2008). The sequence was also submitted to the BLASTn search engine of GenBank using the "nucleotide blast" program against the nucleotide collection (nr/nt) database (http://www.ncbi.nlm .nih.gov/BLAST). For all sequences, genetic identity scores (GIS) and E-values are reported. The GIS is the percentage of aligned nucleotide sites that are the same between the unknown sample and the genetic database samples. The E-value describes the number of different sequence alignments with matching scores equal to or greater than that observed and that is expected to occur in a database search by chance; the lower the E-value (to a minimum of 0 ), the more significant is the observed match.

\section{Results}

In 2013, four species were found in the West, End, and Little End lakes. Both Little End Lake and End Lake had Coastal Cutthroat Trout (Oncorhynchus clarkii clarkii), Coho Salmon, and Dolly Varden char (Salvelinus malma) whereas West Lake only had fish putatively identified as Coho Salmon and Threespine Stickleback (Gasterosteus aculeatus). Smaller salmonids resembled typical Coho Salmon with obvious parr marks and falcate (sickle-shaped) anal fins with black and sometimes white trailing edges (McPhail 2007). Larger individuals (up to $36.0 \mathrm{~cm}$ fork length) had anal fins that were longer than the fin ray base indicating that these unknown Oncorhynchus were not Coastal Cutthroat Trout or Rainbow Trout. In fact, they superficially resembled Kokanee (non-anadromous Sockeye Salmon, O. nerka); they were "silvery" in overall colouration and had clear anal fins, deciduous scales, no visible parr marks, and only very faint spotting on tails (McPhail 2007). Their generally stout and small number ( 16-26) of gill rakers, however, strongly suggested that they were not Kokanee/Sockeye Salmon (gill raker counts generally $>30)$. The branchiostegal ray counts $(\sim 11-15)$ also suggested that these fish were not Chinook Salmon (13-19) and, in fact, were morphologically similar to Coho Salmon.

After molecular analyses, all 42 Oncorhynchus were positively identified as Coho Salmon, O. kisutch, as they all had the GH-2 alleles that were less than 120 base pairs (bp) and most were 112-114 bp in size. Chinook Salmon and Rainbow Trout are characterized by 120 and $124 \mathrm{bp}$ alleles, respectively. The first nine fish (nos. 1-9) were also assayed at the $\mathrm{CO} 1$ gene and all sequences were positively identified as Coho Salmon using the GENBANK database (\% identity $=92-99 \%$, E-values all zero) as well as the BOLD identification engine with $100 \%$ placement accuracy.

The Coho Salmon sampled in 2013 ranged in fork length from 11.9 to $36.2 \mathrm{~cm}$ across the three lakes, and were generally larger and older in West Lake than in End Lake and Little End Lake (Table 1). A few age-0 and age-1 Coho Salmon were captured but, in general, smaller and younger salmonids were not present in the samples from any of the lakes. Thirteen of the fish were maturing as indicated by enlarged gonads (Figure 2) and all were from West Lake; there were 12 males and one female. All mature fish from West Lake were at least $29.0 \mathrm{~cm}$ in fork length and were aged four and five years old, compared to average fork lengths of $26.7 \mathrm{~cm}( \pm 5.0 \mathrm{~cm}$ and $3.0+\mathrm{yr}$ (range $1+$ to $5+)$, respec- 
tively in the lake. Coho Salmon from Little End and End lakes were smaller (mean $\pm \mathrm{SD}=20.6 \pm 4.5 \mathrm{~cm}$, $n=22$, and $18.3 \pm 4.2 \mathrm{~cm}, n=12$, respectively) and younger $(1.4 \mathrm{yr}+$, range $0+$ to $3+$, and $1.3 \mathrm{yr}+$, range $0+$ to $3+$ ) than those of West Lake.

In 2015, six fish species were collected in Lak007, three in Lak016, and two in Lak034. Using the morphological characters that were validated with genetic analysis in 2013, Coastal Cutthroat Trout were found in all three lakes, while Lak007 and Lak016 also had Coho Salmon and Dolly Varden char, but Lak034 had only Coastal Cutthroat Trout and Threespine Stickleback. Chinook Salmon, Rainbow Trout, and Prickly Sculpin (Cottus asper) were also found in Lak007. The three Coho Salmon captured from Lak016 in 2015 were also large, all exceeded $34.0 \mathrm{~cm}$ fork length (mean = $35.0 \pm 8.0 \mathrm{~cm}$, were $3+$ to $4+$ in age, and all were mature females (Table 1). Coho Salmon captured in Lak007 were smaller (mean $=18.8 \pm 2.0 \mathrm{~cm}, n=7$ ) and younger (all ages were $0+$ to $1+, n=6$ ) than those in Lak016 and all were immature (Table 1).

\section{Discussion}

The presence of large, mature fish that have not migrated to the ocean is a very uncommon observation for Coho Salmon in their native range, especially for females. We did not have the opportunity to examine the otoliths of the mature fish that we encountered to see if microchemistry signals in these otoliths indicated a lack of migration to the sea (e.g., see Zimmerman 2005) and future studies should endeavour to seek such confirmation. It is, however, highly unlikely that the mature Coho Salmon we found had ever been to sea. First, only End Lake had any perceptible outlet draining the lake during the normal anadromous migration time of Coho Salmon. The area downstream of the lakes is flat relief marsh habitat with no defined stream channels. Salmon, therefore, likely only have opportunistic access to the lakes from the anadromous portions of the Skeena River drainage (i.e., during high water events). Although End Lake has a defined outlet, it quickly transforms into marsh-like habitat within forest cover and no clear stream channel downstream of the outlet. Second, while Coho Salmon may mature as precocial "jack" males after only approximately six months at sea, these fish are typically $2+$ in total age (e.g., Foerster and Ricker 1953; Sandercock 1991) whereas the mature fish we found were $3+$ to $5+$ years old. Finally, "jack" Coho Salmon are exclusively male (Sandercock 1991), yet we observed four mature female Coho Salmon in the two lakes.

Coho Salmon rearing in lakes as age- $0+$ fish is relatively common, but their size in the autumn of their first year is rarely greater than $100 \mathrm{~mm}$ and most emigrate to the ocean as age-1+ smolts at sizes of less than $200 \mathrm{~mm}$ (Sandercock 1991; Irvine and Johnston 1992). The age$0+$ Coho Salmon in the lakes that we sampled appear to resemble other lake-dwelling Coho Salmon, i.e., that have duller fin colours and less falcate anal fins than their stream-dwelling counterparts (Swain and Holtby 1989). Lake-dwelling Coho Salmon were also found to be less aggressive than stream-dwelling Coho Salmon, which is likely a result of decreased territorial and station-holding behaviour in lake environments (Swain and Holtby 1989).

The mature Coho Salmon captured in 2013 were all from West Lake and only one of these fish was a female. The three mature fish captured from Lake 016 in 2015 were all female. The differences between lakes in the apparent sex ratio of mature Coho Salmon is likely a result of low sample sizes and not any kind of sex-bias in freshwater maturation as reported in other salmonids (e.g., Myers et al. 1986; Taylor 1989). In the latter species, precocial maturation of largely male fish has been suggested to result from sex-related differences in the tradeoffs between the benefits of seaward migration to exploit higher growth opportunities in marine environments and its relationship to increased fecundity in females versus the presumably much lower relative benefit for sperm production in males (Hendry et al. 2004). By contrast, the mature Coho Salmon that we observed apparently had no opportunity to migrate to sea during the period 2013-2015.

Non-anadromous Coho Salmon populations are common in the Great Lakes, where they were first introduced in the 1960s (Sandercock 1991; Rand and Stewart 1998), which indicates that there is no physiological reason that Coho Salmon must migrate to the ocean to mature. Maturation of non-andromous Chinook Salmon males across their native range is common (e.g., Gebhards 1960; Taylor 1989; Foote et al. 1991; Johnson et al. 2012), but observations of non-anadromous Coho Salmon maturation within their native range are rare (Foerster and Ricker 1953). The observation of mature male and female Coho Salmon in two lakes is interesting because it suggests that coastal populations may include some individuals that do not migrate to sea and may mature and reproduce in fresh water. The degree to which such freshwater-resident forms may be reproductively-isolated from sympatric anadromous forms is a question that has been addressed in several other species of salmonid fishes (e.g., Foote et al. 1989; Verspoor and Cole 1989). The existence of sympatric and reproductively-isolated populations within a taxon is increasingly recognized as an important component of conservation planning (Taylor 1999; Wood et al. 2008). Alternatively, the mature Coho Salmon may simply have been a response to an ephemeral restriction in the opportunity to migrate seaward owing to low water levels in the spring when Coho Salmon typically migrate to sea after 1-2 years in fresh water (Sandercock 1991). For instance, plasticity in the timing of migration to the sea by smolts as a response to minor freshets has been noted in some populations (Irvine and Ward 1989).

Interestingly, we detected very few age- $0+$ Coho Salmon in the lakes that we sampled despite using fine 

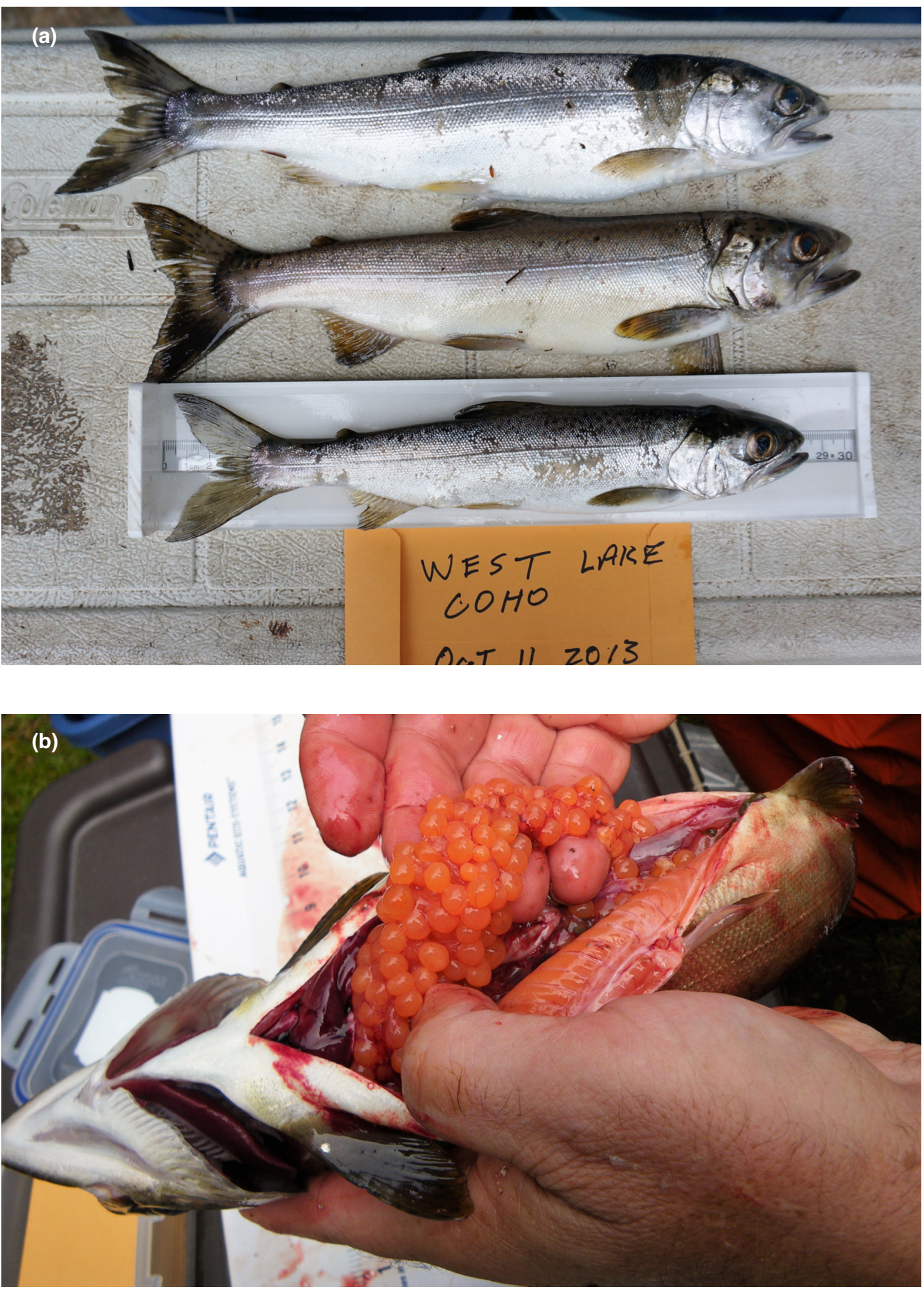

FIGURE 2. Image of (a) mature male and female Coho Salmon (Oncorhynchus kisutch), and (b) a single mature female Coho Salmon from West Lake, British Columbia, Canada. In the top image the middle fish is a mature male, the top and the bottom fishes are immature females. The measuring board is $30 \mathrm{~cm}$ long. Photos: Eric A. Parkinson. 
mesh nest that have been shown to capture juvenile Rainbow Trout of similar age/size (Askey et al. 2007). Consequently, we should have detected more young Coho Salmon if they were common. The absence of age $0+$ Coho Salmon in the lakes raises two possibilities. First, if Coho Salmon do spawn as freshwater residents in these systems (e.g., on submerged beaches), perhaps survival of lake-spawned fish is very low or they enter tributary streams for a year or more before re-entering the lakes. Alternatively, perhaps young Coho Salmon result from spawning in tributary streams and they spend the first year or two of life in these streams before entering the lakes. These lakes, however, are at the edge of a flat gravel plateau and examination of air photos and the 1:20000 provincial watershed atlas suggests that inlet tributary streams are rare and although all lakes have outlet streams and some have second order tributary that enter these outlets, access to these lakes may be limited by drought or beaver dams from time to time. On balance, therefore, it appears most likely that it is intermittent access to lakes from tributary streams that results in episodic occurrence of mature Coho Salmon in the lakes.

Regardless of the unknown aspects of the reproductive juvenile ecology of the lake-dwelling Coho Salmon that we have observed, the reproductive plasticity that it represents may be an important aspect of the life history repertoire of Coho Salmon that promotes their persistence in variable and unpredictable environments (Hutchings 2004; Chevin et al. 2010).

\section{Acknowledgements}

Funding for this research was provided by Rio Tinto Alcan Ltd. (RTA) and by Natural Sciences and Engineering Research Council of Canada Discovery and Equipment grants awarded to E.B.T. The people at RTA who accessed the funding and worked closely with the authors included ShawnZettler and Marc Cuellar-Roerhi. The authors were assisted in the field by Shauna Bennett and Fred Seiler. Stephanie Lingard completed the fish scale aging. Meaghan Leslie-Gottschligg prepared the study site map. We thank Dave Marmorek, Carol Murray, and Patrick Williston for numerous discussions of study findings within the larger assessment project and we appreciate the reviewers' comments.

\section{Literature Cited}

Allendorf, F. W., D. Bayles, D. L. Bottom, K. P. Currens, C. A. Frissell, D. Hankin, J. A. Lichatowich, W. Nehlsen, P. C. Trotter, and T. H. Williams. 1997. Prioritizing Pacific salmon stocks for conservation. Conservation Biology 11: 140-152.

Askey, P., J. Post, E. Parkinson, E. Rivot, A. Paul, and P. Biro. 2007. Estimation of gillnet efficiency and selectivity across multiple sampling units: a hierarchical Bayesian analysis using mark-recapture data. Fisheries Research 83: 162-174.

Behnke, R. J. 1992. Native trout of western North America. American Fisheries Society monograph (USA). No. 6, Bethesda, Maryland, USA.
Behnke, R. J. 2002. Trout and Salmon of North America. The Free Press, New York, New York, USA.

Berg, L. S. 1948. Freshwater Fishes of the USSR and Adjacent Countries, Volume 1. Opred. Faune SSSR 27: (Translated from Russian; Israel Program for Scientific Translations, Jerusalem, 1963), St. Petersburg, Russia.

Blanchfield, P. J., E. B. Taylor, and D. J. Watkinson. 2014. Morphological and genetic analyses identify a new record of a glacial relict; pygmy whitefish (Prosopium coulterii) from northwestern Ontario. Canadian Journal of Zoology 92: 267-271.

Chevin, L. M., R. Lande, and G. M. Mace. 2010. Adaptation, plasticity, and extinction in a changing environment: towards a predictive theory. PLoS Biology 8: e1000357.

Crête-Lafrenière, A., L. K. Weir, and L. Bernatchez. 2012. Framing the Salmonidae family phylogenetic portrait: a more complete picture from increased taxon sampling. PLoS One 7: e46662.

ESSA Technologies Ltd. 2015. Sulphur dioxide environmental effects monitoring for the Kitimat Modernization Project - 2013 and 2014 Annual Reports. Prepared for Rio Tinto Alcan, Kitimat, British Columbia, Canada.

Foerster, R. E., and W. E. Ricker. 1953. The coho salmon of Cultus Lake and Sweltzer Creek. Journal of the Fisheries Board of Canada 10: 293-319.

Foote, C. J., C. C. Wood, and R. E. Withler. 1989. Biochemical genetic comparison of sockeye salmon and kokanee, the anadromous and nonanadromous forms of Oncorhynchus nerka. Canadian Journal of Fisheries and Aquatic Sciences 46: 149-158.

Foote, C. J., W. C. Clarke, and J. Blackburn. 1991. Inhibition of smolting in precocious male chinook salmon, Oncorhynchus tshawytscha. Canadian Journal of Zoology 69: 1848-1852.

Gebhards, S.V. 1960. Biological notes on precocious male chinook salmon parr in the Salmon River drainage, Idaho. Progressive Fish Culturalist 22: 121-123.

Greig, C., J. M. Robertson, and M. A. Banks. 2002. Rapid PCR-based species tests for sympatric salmonids. Conservation Genetics 3: 83-86.

Groot, C., and L. Margolis. 1991. Pacific Salmon Life Histories. University of British Columbia Press, Vancouver, Canada.

Hendry, A. P., and S. C. Stearns. 2004. Evolution Illuminated. Salmon and their Relatives. Oxford University Press, Oxford, UK.

Hendry, A. P., T. Bohlin, B. Jonsson, and O. K. Berg. 2004. To sea or not to sea? Anadromy versus non-anadromy in salmonids. Pages 92-125 in Evolution Illuminated. Salmon and their Relatives. Edited by A. P. Hendry and S. C. Stearns. Oxford University Press, Oxford, UK.

Hubert, N., R. Hanner, E. Holm, N. E. Mandrak, E. B. Taylor, M. Burridge, D. Watkinson, P. Dumont, A. Curry, P. Bentzen, J. Zhang, J. April, and L. Bernatchez. 2008. Identifying Canadian freshwater fishes through DNA barcodes. PLoS ONE 3: e2490.

Hutchings, J. A. 2004. Norms of reaction and phenotypic plasticity in salmonid life histories. Pages 154-174 in Evolution Illuminated. Salmon and their Relatives. Edited by A. P. Hendry and S. C. Stearns. Oxford University Press, Oxford, UK.

Irvine, J. R., and B. R. Ward. 1989. Patterns of timing and size of wild coho salmon (Oncorhynchus kisutch) smolts migrating from the Keogh River watershed on northern 
Vancouver Island. Canadian Journal of Fisheries and Aquatic Sciences 46: 1086-1094.

Irvine, J. R., and N. T. Johnston. 1992. Coho salmon (Oncorhynchus kisutch) use of lakes and streams in the Keogh River drainage, British Columbia. Northwest Science 66: 15-25.

Irvine, J. R., and G. A. Fraser. 2008. Canada's wild Pacific salmon policy and the maintenance of diversity. American Fisheries Society Symposium 49: 391-398.

Johnson, J., T. Johnson, and T. Copeland. 2012. Defining life histories of precocious male parr, minijack, and jack chinook salmon using scale patterns. Transactions of the American Fisheries Society 141: 1545-1556.

Lackey, R. T., D. Lach, and S. L. Duncan. 2006. Salmon 2100: the future of wild Pacific salmon. American Fisheries Society, Bethesda, Maryland, USA.

McDowell, R. M. 1987. The occurrence and distribution of diadromy among fishes. American Fisheries Society Symposium 1: 1-13.

McDowell, R. M. 1990. New Zealand Freshwater Fishes: A Natural History and Guide. Heinemann Reed, Auckland, New Zealand.

McPhail, J. D. 2007. The Freshwater Fishes of British Columbia. The University of Alberta Press, Edmonton, Alberta, Canada.

Myers, R. A., J. A. Hutchings, and R. J. Gibson. 1986. Variation in male parr maturation within and among populations of Atlantic salmon, Salmo salar. Canadian Journal of Fisheries and Aquatic Sciences 43: 1242-1248.

Phillips, A. C. 1977. Key field characters of use in identifying young marine Pacific salmon. Canadian Fisheries and Marine Service Technical Report 746.

Quinn, T. P. 2011. The Behavior and Ecology of Pacific Salmon and Trout. University of British Columbia Press, Vancouver, British Columbia, Canada.

Rand, P. S., and D. J. Stewart, 1998. Prey fish exploitation, salmonine production, and pelagic food web efficiency in Lake Ontario. Canadian Journal of Fisheries and Aquatic Sciences 55: 318-327.

Ratnasingham, S., and P. D. N. Hebert. 2007. BOLD: The Barcode of Life Data System (www.barcodinglife.org). Molecular Ecology 7: 355-364.

RIC (Resources Inventory Committee). 1997. Fish Collection Methods and Standards. Prepared by the B.C. Ministry of Environment, Lands and Parks, Fish Inventory Unit for the Aquatic Ecosystems Task Force, Resources Inventory Committee (RIC).

Ricker, W. E. 1940. On the origin of kokanee, a fresh-water type of sockeye salmon. Transactions Royal Society of Canada 34 (Sect. 5): 121-135.

Rousenfell, G. A. 1958. Anadromy in North American Salmonidae. Fishery Bulletin 58: 171-185.

Sandercock, F. K. 1991. Life history of coho salmon (Oncorhynchus kisutch). Pages 395-445 in Pacific Salmon Life Histories. Edited by C. Groot and L. Margolis. University of British Columbia Press, Vancouver, Canada.
Schmidt, P. Y. 1950. Fishes of the Sea of Okhotsk. Izdatelstvo Akademii Nauk, Moscow, Russia (original in Russian).

Smith, G. R., and R. F. Stearley. 1989. The classification and scientific names of rainbow and cutthroat trouts. Fisheries 14: 4-10.

Swain, D. P., and L. B. Holtby. 1989. Differences in morphology and behavior between juvenile coho salmon (Onchorhynchus kisutch) rearing in a lake and in its tributary stream. Canadian Journal of Fisheries and Aquatic Sciences 46: 1406-1414.

Taylor, E. B. 1989. Precocial male maturation in laboratoryreared populations of chinook salmon, Oncorhynchus tshawytscha. Canadian Journal of Zoology 67: 1665-1669.

Taylor, E. B. 1999. Species pairs of north temperate freshwater fishes: evolution, taxonomy, and conservation. Reviews in Fish Biology and Fisheries 9: 299-324.

Taylor, E. B., P. Tamkee, E. R. Keeley, and E. A. Parkinson. 2011. Conservation prioritization in widespread species: the use of genetic and morphological data to assess population distinctiveness in rainbow trout (Oncorhynchus mykiss) from British Columbia, Canada. Evolutionary Applications 4: 100-115.

Trautman, M. B. 1973. A guide to the collection and identification of presmolt Pacific salmon in Alaska with an illustrated key (Volume 2). United States Department of Commerce, National Oceanic and Atmospheric Administration, Seattle, Washington, USA.

Verspoor, E., and L. J. Cole. 1989. Genetically distinct sympatric populations of resident and anadromous Atlantic salmon, Salmo salar. Canadian Journal of Zoology 67: 14531461.

Ward, B. R., and P. A Slaney. 1988. Life history and smoltto-adult survival of Keogh River steelhead trout (Salmo gairdneri) and the relationship to smolt size. Canadian Journal of Fisheries and Aquatic Sciences 45: 1110-1122.

Ward, H. G. M., P. J. Askey, J. R. Post, D. A. Varkey, and M. K. McAllister. 2012. Basin characteristics and temperature improve abundance estimates from standard index netting of rainbow trout (Oncorhynchus mykiss) in small lakes. Fisheries Research 131-133: 52-59.

Ward, R. D., T. S. Zemlak, B. H. Innes, P. R. Last, and P. D. N. Hebert. 2005. DNA barcoding Australia's fish species. Philosophical Transactions of the Royal Society Series B 360: 1847-1857.

Wood, C. C., J. W. Bickham, R. J. Nelson, C. J. Foote, and J. C. Patton. 2008. Recurrent evolution of life history ecotypes in sockeye salmon: implications for conservation and future evolution. Evolutionary Applications 1: 207-221.

Zimmerman, C. E. 2005. Relationship of otolith strontiumto-calcium ratios and salinity: experimental validation for juvenile salmonids. Canadian Journal of Fisheries and Aquatic Sciences 62: 88-97.

Received 28 May 2016

Accepted 14 October 2016 